\title{
PEMBENTUKAN KUALITAS ANAK PADA 1000 HARIPERTAMA KEHIDUPAN PERSPEKTIF HUKUM ISLAM
}

\author{
Siti Tatmainul Q ulub \\ Nungky_diamond@yahoo.com \\ Univeritas Islam N egeri Sunan \\ A mpel Jl. A. Yani 117 Surabaya
}

\begin{abstract}
The quality of a child is influenced by two determining factors, namely genetic factor and environmental factor. These factors influence is very large, especially during the first 1,000 days of life of a child, starting from the time of pregnancy to breastfeeding until the age of 2 years. W hen the baby's vital organs begin to form, together with it also the baby started to feel on a given stimulus, record and imitate communication and habits performed by his mother that he will take up next. Lack of stimulation and nutrition, especially during this period, will have a major impact in the long term life. Islam has provided guidance to establish quality of a child at 1,000 days of life. During p regnancy, many parents are encouraged to be grateful and be merry, to eat halal and good food, to reproduce worship, etc. After the birth, they are led to recite âdhân and iqâmah for a newborns, to give a good name, and breast feeding for 2 full years.
\end{abstract}

Keyword s: Q uality of kid, the first 1,000 days of life, Islamic law.

\begin{abstract}
Abstrak: Kualitas anak dipengaruhi oleh dua faktor pembentuk, yakni faktor genetik dan faktor lingkungan. Faktor-faktor tersebut berpengaruh sangat besar terutama saat 1000 hari pertama kehid upan (HPK) anak, yang dimulai sejak masa kehamilan hingga menyusui sampai usia anak 2 tahun. Ketika organ-organ penting bayi mulai terbentuk, bersamaan itu juga bayi mulai dapat merasakan stimulus yang diberikan dari luar, merekam dan menirukan komunikasi serta kebiasaan-kebiasaan yang dilakukan oleh ibunya yang akan ia bawa hingga seterusnya. Kurangnya rangsangan dan terutama gizi pada masa ini, akan berdampak besar dalam jangka panjang kehid upannya. Islam telah memberikan tuntunan untuk membentuk anak yang berkualitas pada 1000 HPK. Pada masa kehamilan, orang tua dianjurkan banyak bersyukur dan bergembira, makan makanan yang halal dan baik, memperbanyak ibadah, dsb. Setelah kelahiran, dituntun untuk membacakan adzan dan iqamah pada bayi yang baru lahir, memberikan nama yang baik, dan menyusui anak selama 2 tahun penuh.
\end{abstract}

Kata Kunci: Anak berkualitas, 1000 hari pertama kehid upan, hukum Islam 


\section{Pendahuluan}

Setiap orang tua menginginkan anak yang sehat, cerdas dan berakhlak mulia. Keberadaan anak yang demikian tidak bisa didapatkan begitu saja. Banyak penelitian yang menyebutkan bahwa potensi kecerdasan atau kualitas anak dipengaruhi oleh faktor-faktor pembentuk. Faktor-faktor itulah yang bisa membentuk kualitas seorang anak yang dapat dinilai dari proses tumbuh kembangnya.

Proses tumbuh kembang merupakan hasil interaksi antara faktor genetik dan faktor lingkungan. Sehingga, faktor pembentuk kualitas anak dapat dibagi menjadi dua, yakni: faktor genetik/keturunan dan faktor lingkungan. Faktor genetik/keturunan adalah faktor yang berhubungan dengan gen yang berasal dari ayah dan ibu, sedangkan faktor lingkungan meliputi lingkungan biologis, fisik, psikologis, dan sosial. ${ }^{1}$

Disebutkan bahwa $1000 \mathrm{H}$ ari Pertama Kehidupan (HPK) merupakan 'golden age periode' dari pertumbuhan dan perkembangan anak yang sangat menentukan kehidupan anak selanjutnya. Periode tersebut tidak hanya dimulai sejak lahir, namun dimulai sejak usia nol kehamilan sampai usia 2 tahun.

Pada $1000 \mathrm{H}$ ari Pertama Kehidupan tersebut, yang dimulai sejak masa kehamilan hingga menyusui sampai usia anak 2 tahun, merupakan waktu ketika organ-organ penting bayi mulai terbentuk, terutama pada masa di dalam kandungan (pranatal). Bersamaan dengan itu juga, bayi mulai dapat merasakan stimulus yang diberikan dari luar, merekam dan menirukan komunikasi serta kebiasaan-kebiasaan yang dilakukan oleh ibunya yang akan ia bawa hingga seterusnya.

Islam sebagai agama yang universal dan komplit, telah membahas tentang masa kehamilan, sebagaimana dituliskan dalam al-Q ur'an surat al-M ukminun ayat 12-14. Islam juga mengajarkan perlunya pendidikan pralahir atau pranatal dalam QS. al-A'raf: 172:

" $D$ an (ingatlah), ketika Tuhanmu mengeluarkan keturunan anakanak Adam dari sulbi mereka dan Allah mengambil kesaksian terhadap jiwa mereka (seraya berfirman): "Bukankah Aku ini Tuhanmu?" M ereka menjawab: "Betul (Engkau Tuhan kami), kami menjadi saksi". (Kami lakukan yang demikian itu) agar di

\footnotetext{
${ }^{1}$ Atien Nur Hamidah, "Pentingnya Stimulasi Dini Bagi Tumbuh Kembang 0 tak Anak", materi Talk Show Tumbuh Kembang dan Kesehatan Anak di UNY tanggal 170 ktober 2009.
} 
hari kiamat kamu tidak mengatakan: "Sesungguhnya kami (bani Adam) adalah orang-orang yang lengah terhadap ini (keesaan Tuhan)."

Dalil di atas menunjukkan bahwa anak dalam kandunganpun dapat menerima pendidikan yang diarahkan padanya, karena sebenarnya ia telah hidup berkat ruh (dari) Allah yang ditiupkan padanya. Ruh itu yang kelak akan mengemban amanah dan perintah Allah supaya beribadah kepada- $\mathrm{N}$ ya semata, hingga mempertanggungjawabkan amal perbuatannya di hadapan Allah.

Salah satu upaya agar anak dapat mengenal Penciptanya dan beribadah pada-N ya adalah tanggung jawab orangtua yang membesarkannya dengan didikan tauhid dari sejak kehidupan pertamanya (dalam kandungan). Dalam hal ini sang ibu memiliki andil paling besar, karena anak dapat dididik secara aktif sejak ia masih berada dalam kandungan ibunya. Pendidikan inilah yang akan menjadi pondasi pendidikan anak tersebut kelak setelah lahir.

Perkembangan anak juga sangat dipengaruhi oleh perilaku orangtua, bahkan sejak dalam kandungan. Sebagaimana cerita Rasulullah saw. "Suatu hari Nabi Muhammad SAW mengunjungi salah seorang sahabatnya. Di rumah sahabatnya itu $\mathrm{N}$ abi menyaksikan anak sang sahabat meloncat-loncat sambil menginjak bahu dan kepala bapaknya. Lalu $\mathrm{N}$ abi mencari tahu mengapa si anak bisa berperilaku demikian. Kata N abi, "Apakah ada sesuatu makanan yang keliru masuk ke perut istrimu saat sedang mengandung?" "Benar", jawab sahabatnya. Ketika sang istri mengandung, ia memberi sebiji korma yang diambil dari sebuah kebun tanpa seizin pemiliknya. $\mathrm{N}$ abi mengangguk-angguk ketika mendengar penuturan tersebut.

$\mathrm{Hal}$ ini menjadi bukti bahwa mendidik anak sudah harus dimulai sejak anak masih berada dalam kandungan. M akanan yang dimakan sang ibu harus halal dan berkah, serta didikan secara fisik.

Saat ini banyak sekali informasi tentang bagaimana membentuk seorang anak yang cerdas dan sehat sejak dalam kandungan. M ulai dari stimulasi musik, dsb. $\mathrm{N}$ amun bagaimana sebenarnya I slam mengajarkan kepada umatnya dalam membentuk kualitas anak pada $1000 \mathrm{H}$ ari Pertama Kehidupan, serta bagaimana korelasi antara ajaran-ajaran Islam tersebut terhadap karakter seorang anak. 


\section{Anak Berkualitas dan Faktor pembentuknya}

Anak merupakan individu yang berada dalam satu rentang perubahan perkembangan yang dimulai dari bayi hingga remaja. $M$ asa anak merupakan masa pertumbuhan dan perkembangan yang dimulai dari bayi (0-1 tahun) usia bermain/oddler (1-2,5 tahun), pra sekolah (2,5-5), usia sekolah (5-11 tahun) hingga remaja (11-18 tahun). ${ }^{2}$

Antara anak satu dengan yang lain memiliki rentang yang berbeda, mengingat latar belakang anak berbeda. Adakalanya rentang perubahan pertumbuhan dan perkembangan itu cepat dan adakalanya lambat. D alam proses perkembangan anak memiliki ciri fisik, kognitif, konsep diri, pola koping dan perilaku sosial.

Anak adalah individu yang rentan karena perkembangan kompleks yang terjadi di setiap tahap masa kanak-kanak dan masa remaja. Lebih jauh, anak juga secara fisiologis lebih rentan dibandingkan orang dewasa, dan memiliki pengalaman yang terbatas, yang memengaruhi pemahaman dan persepsi mereka mengenai dunia.

Anak yang berkualitas dibentuk dari tumbuh kembangnya. Tumbuh kembang merupakan dasar dari ilmu kesehatan anak, karena ilmu ini mempelajari perubahan-perubahan yang terjadi dalam proses kehidupan sejak konsepsi sel telur dengan sperma, kehidupan janin dalam rahim, masa bayi, anak kecil, masa prasekolah, remaja hingga menjadi masa dewasa. $\mathrm{H}$ al ini dipelajari agar seorang anak dapat tumbuh dan berkembang melalui tahap-tahap pertumbuhan dan perkembangan, baik fisik, mental, emosi dan sosial sesuai dengan potensi yang dimilikinya agar menjadi manusia dewasa yang berguna bagi diri dan lingkungannya. Secara khusus, dengan memahami proses tumbuh kembang, maka kelainan yang terjadi pada proses ini dapat dideteksi secara dini dan ditangani permasalahannya. ${ }^{3}$

Pengertian tumbuh kembang yang dalam kehidupan sehari-hari telah mempunyai satu makna sendiri, sebenarnya mencakup 2 pengertian yang berbeda, tetapi tetap saling berkaitan dan sulit dipisahkan, yaitu pertumbuhan dan perkembangan. Pertumbuhan (growth) adalah semua perubahan dalam jumlah, besar, ukuran atau dimensi pada tingkat sel, organ maupun individu, dan ini bisa diukur dengan ukuran berat,

\footnotetext{
${ }^{2}$ A. A zis A limul Hidayat, Pengantar Ilmu Keperawatan Anak 1 (Jakarta: Salemba M edika, 2005).

${ }^{3}$ Suganda T. Kebutuhan Dasar Tumbuh Kembang Anak. Dalam Tumbuh Kembang Anak dan Remaja, editor M oersintowati, dkk. Edisi I, Ikatan Dokter Anak Ind onesia, 2002.
} 
panjang dan umur tulang. Jadi lebih mengarah pada kuantitas dan mempunyai dampak terhadap aspek fisik. Perkembangan (development) adalah perubahan dalam hal fungsi dan proses pematangan sel maupun organ dan individu, termasuk perkembangan emosi, intelektual dan tingkah laku. D alam hal ini lebih mengarah pada kualitas. ${ }^{4}$

Dengan adanya perkembangan ilmu dan teknologi yang maju, membuat manusia bisa memprediksi kebutuhan-kebutuhan yang harus dipenuhi untuk kehidupan seorang anak di masa yang akan datang. ${ }^{5}$

Ada dua faktor yang mempengaruhi tumbuh kembang anak yaitu faktor genetik ${ }^{6}$ dan faktor lingkungan (milleu). Faktor genetik/keturunan adalah faktor yang berhubungan dengan gen yang berasal dari ayah dan ibu, sedangkan faktor lingkungan meliputi lingkungan biologis, fisik, psikologis, dan sosial. ${ }^{7}$

Kebutuhan fisis-biomedis atau asuh mencakup kebutuhan nutrisi yang seimbang dan tepat, perawatan kesehatan dasar, pakaian, perumahan, higienis diri dan lingkungan serta kesegaran jasmani. N utrisi memegang peranan paling penting dalam memenuhi kebutuhan asuh ini. Anak yang sehat akan tumbuh dan berkembang dengan baik, sedangkan anak yang sering sakit akan terganggu pula tumbuh kembangnya.

Faktor lingkungan yang baik harus dapat menyediakan segala kebutuhan dasar anak untuk dapat tumbuh kembang optimal, yang kita kenal dengan asuh, asah dan asih. Asuh berupa kebutuhan fisis-biomedis, asah bermakna kebutuhan latihan/rangsangan/bermain/stimulasi, asih berarti kebutuhan akan kasih sayang/emosi. ${ }^{8}$

Berkaitan dengan hal ini, al-Ghazali menyatakan bahwa setiap manusia lahir membawa fitrah sebagai potensi dasar, yang untuk

\footnotetext{
${ }^{4}$ Soetjiningsih, Tumbuh Kembang Anak (Jakarta: Penerbit Buku Kedokteran EGC, 1995).

${ }^{5}$ Moersintowarti BN, Tumbuh kembang Anak dan Remaja, Buku ajar I (Jakarta: Penerbit CV Sagung Seto, 2004).

${ }^{6}$ Dalam bahasa al-Ghazali disebut dengan fungsi hereditas/p embawaan.

${ }^{7}$ Atien Nur Hamidah, Pentingnya Stimulasi Dini Bagi Tumbuh Kembang 0 tak Anak, materi Talk Show "Tumbuh Kembang dan Kesehatan Anak" di UNY tanggal 170 ktober 2009. Dalam bahasa al-Ghazali, fungsi pembawaan menumbuhkan fungsi-fungsi dan kapasitas, sedangkan lingkungan mengembangkan fungsi-fungsi dan kapasitas itu. Baik stimuli hereditas/pembawaan maupun stimuli lingkungan berinteraksi saling mempengaruhi untuk menimbulkan proses pertumbuhan dan perkembangan. Lihat dalam W asti Sumanto, Psikologi Pendidikan (Jakarta: Rineka Cipta, 1990), 61.

${ }^{8}$ Titi Sularyo, Tumbuh kembang Anak dan Remaja, Buku ajar I (Jakarta: Penerbit CV Sagung Seto, 2002).
} 
selanjutnya ditentukan oleh lingkungannya. Karena itu, orangtua diharapkan mampu mengemban amanah, sebab jiwa yang suci ini akan berkembang sesuai dengan bimbingan orangtuanya. $M$ anusia sejak lahir dibekali dengan fitrah yang berupa kemampuan dasar untuk berbuat, maka sesungguhnya manusia memiliki potensi untuk menjadi manusia berperangai baik atau buruk. ${ }^{9}$

\section{Periode $1000 \mathrm{H}$ ari Pertama Kehidupan Manusia}

Periode 1000 hari pertama kehidupan terdiri dari 270 hari selama kehamilan dan 730 hari dari kelahiran sampai usia 2 tahun. Dengan demikian, 1000 hari pertama kehidupan terjadi pada saat ibu hamil dan menyusui hingga usia anak 23 bulan. ${ }^{10}$

Periode 1000 hari pertama kehidupan merupakan periode kritis dalam kehidupan manusia dan memberikan dampak jangka panjang terhadap kesehatan dan fungsinya. Dampak yang ditimbulkan malnutrition pada periode ini bersifat permanen dan berjangka panjang.

Pada kehamilan 8 minggu pertama sejak pembuahan terjadi pembentukan semua cikal bakal yang akan menjadi otak, hati, jantung, ginjal, tulang, dan lain-lain. Kemudian kehamilan 9 minggu hingga kelahiran, merupakan pertumbuhan dan perkembangan lebih lanjut pada organ tubuh agar siap untuk hidup di dunia baru atau di luar kandungan ibu. Perkembangan penting sebagian organ terus berlanjut sampai kirakira 2 tahun pertama kehidupan. D engan demikian, sebagian besar organ dan sistem, masa kritisnya terjadi pada saat periode dalam kandungan.

Pembentukan dan perkembangan fungsi otak mulai terbentuk dari sejak masa kehamilan. Pada kehamilan 6-24 minggu terjadi pembentukan sistem syaraf. Selanjutnya hingga lahir mengalami perkembangan fungsi. Kemudian pada umur 0-2 tahun merupakan puncak perkembangan fungsi melihat, mendengar, berbahasa, dan fungsi kognitif yang lebih tinggi. Setelah usia >2-3 tahun, fungsi kognitif yang tinggi menurun. ${ }^{11}$

\footnotetext{
${ }^{9}$ Al-Ghazali, Ihya' U lumudd in Juz III (Semarang: M aktabah wa Mathba'ah Toha Putra), 78.

${ }^{10} \mathrm{~T}$ im Penyusun, Pedoman Perencanaan Program Gerakan 1000 Hari Pertama Kehidupan (Jakarta, 2013), 8.

${ }^{11}$ Endang L. Achadi, Periode Kritis 1000 Hari Pertama Kehidupan dan Dampak Jangka Panjang Terhadap Kesehatan dan Fungsinya. Dalam kursus penyegar ilmu gizi yang diselenggarakan oleh PERSAGI, di Yogyakarta, 25 Novemb er 2014.
} 
O leh karena itu, segala hal yang diperlukan oleh janin dan bayi pada 1000 hari pertama kehidupan tersebut harus dipenuhi, karena akan sangat besar dampaknya terhadap kehidupannya kelak. Kebutuhan tersebut meliputi kebutuhan asuh, asah dan asih. Kekurangan gizi yang merupakan salah satu kebutuhan fisik pada masa janin dan usia dini akan memberikan dampak jangka pendek dalam perkembangan otak, pertumbuhan (IUGR), dan metabolic programing. Dampak jangka pendek tersebut, akan membawa pada dampak jangka panjang yaitu; perkembangan otak akan menyebabkan kemampuan kognitif dan pendidikan yang kurang, pertumbuhan (IUGR) akan menyebabkan stunting/pendek, dan metabolic programing akan menyebabkan berbagai penyakit seperti hipertensi, diabetes, obesitas, PJK, dan stroke. ${ }^{12}$

Awalnya penelitian ilmiah tentang perkembangan anak, sebagian besar dimulai dengan bayi yang baru lahir dan mengabaikan periode pranatal. $\mathrm{H}$ al ini karena perkembangan secara fisik baru terlihat ketika bayi telah lahir. Namun ternyata, hasil dari penelitian perkembangan anak ini menghasilkan sedikit sumbangan dalam pemahaman psikologis tentang perkembangan. Saat ini telah ditemukan bahwa periode setelah lahir (pasca natal) merupakan lanjutan dari periode sebelum lahir (pranatal). Sehingga untuk mengetahui perkembangan setelah lahir, harus diketahui pula apa yang terjadi sebelumnya (pra-natal). Kini telah ditemukan bahwa periode pranatal merupakan periode yang sangat penting dalam kehidupan manusia. ${ }^{13}$

Berikut ini adalah penjelasan tentang periode kehamilan (pranatal) dan periode kelahiran (pasca natal) hingga usia anak 2 tahun.

a. Periode kehamilan (pranatal)

Kehidupan janin di dalam rahim ibu (intrauterus) dibagi menjadi tiga fase pertumbuhan yaitu fase germinal (zigot), embrional dan fetus (janin): ${ }^{14}$

1. Fase Germinal (zigot)

Fase ini merupakan awal dari kehidupan manusia, dimulai ketika sperma mengalami fermentasi terhadap sel telur dalam pembuahan, yang normalnya terjadi akibat hubungan seksual

\footnotetext{
${ }^{12} \mathrm{lbid}$.

${ }^{13}$ Elizab eth B. Hurlock, Perkembangan Anak Jilid I (Jakarta: Erlangga, 1999), 52.

${ }^{14}$ Aliah B. Purwakania, Psikologi Perkembangan Islam (Jakarta: Raja Grafindo Persada, 2006), 79 91.
} 
antara suami dan istri. Fase ini berlangsung pada waktu 10-14 hari setelah pembuahan yang akhirnya membentuk zigot. Zigot (hasil pembuahan) berkembang cepat 72 jam setelah pembuahan, membelah diri menjadi 32 sel dan sehari kemudian sudah 72 sel. Pembelahan ini berlangsung terus sampai menjadi 800 milyar sel atau lebih, dan dari sinilah manusia tumbuh berkembang.

D alam fase germinal ini terbentuklah saluran yang menempel pada uterus yang dicapai selama 3-4 hari yang kemudian berubah bentuk menjadi "blastocyst" yang terapung bebas dalam uterus selama satu atau dua hari. Beberapa sel sekitar pinggiran blastocyst membentuk piringan embrionik merupakan massa sel yang tebal dan dari sinilah bayi akan tumbuh. M assa ini mengalami deferensiasi menjadi tiga lapisan, bagian atas yaitu ektoderm, bagian bawah endoderm dan lapisan tengah mesoderm.

Ektoderm merupakan lapisan yang nantinya akan membentuk lapisan kulit luar, kuku, rambut gigi, organ perasa dan sistem syaraf termasuk otak dan sumsum tulang belakang. Endoderm merupakan lapisan bagian bawah yang akan membentuk sistem pencernaan, hati, pancreas, kelenjar ludah, sistem pernafasan. Mesoderm merupakan lapisan tengah (mesoderm) yang akan berkembang dan berdeferensiasi menjadi lapisan kulit bagian dalam, urat daging, kerangka, sistem ekskresi dan system sirkulasi. Bagian lain dari blastocyst tumbuh menjadi plasenta, tali pusat dan kantong empedu. Pada masa ini pula yaitu pada usia embrio 4 minggu, embrio mengeluarkan hormon yang menyebabkan berhentinya siklus haid ibu.

\section{Fase Embrional}

Fase ini berlangsung lima setengah minggu. Berkembang mulai 2-8 minggu setelah pembuahan. Fase embrional dimulai ketika zigot telah tertanam dengan baik pada dinding rahim. Selama fase ini sistem dan organ dasar bayi mulai terbentuk dari susunan sel. Mulai dari sistem pernafasan, pencernaan, sistem syaraf dan tubuh, mulai tumbuh dan berkembang cepat. M eskipun bentuk luar masih jauh berbeda dibandingkan dengan bentuk manusia dewasa, namun beberapa bentuk seperti mata, tangan, dan kaki mulai dapat dikenali. 
Pada periode pertumbuhan embrional ini sangat peka terhadap pengaruh lingkungannya. Keadaan tidak normal atau cacat pada waktu lahir dapat terjadi karena adanya gangguan pada masa kandungan tiga bulan pertama.

Selama periode pertumbuhan embrio terjadi pembelahan sel, dan relatif lebih cepat dari periode lainnya. Pertumbuhan embrio yang cepat tersebut menunjukkan kebutuhan oksigen dan zat gizi tinggi untuk setiap unit massa embrio. $\mathrm{H}$ al ini menyebabkan embrio sensitif terhadap perubahan suplai gizi dan oksigen. Pada saat ketersediaan oksigen menurun atau kekurangan zat gizi tertentu dapat menyebabkan hambatan pertumbuhan yang permanen. ${ }^{15}$

\section{Fase Fetus (Janin)}

Pada fase ketiga kehamilan, embrio disebut fetus (janin). Fase ini berlangsung sekitar 30 minggu. Fase ini dimulai delapan minggu setelah pembuahan hingga saat kelahiran. Sel tulang pertama mulai tumbuh dan embrio menjadi janin. Dari periode ini sampai saat kelahiran bentuk tubuh makin sempurna, bagian-bagian tubuh tumbuh dengan laju yang berbeda-beda dan janin sendiri tumbuh memanjang sampai kira-kira 20 kalinya. Pada fase ini, tangan, wajah dan kaki mulai terlihat seperti bentuk manusia pada umumnya. Selain itu, otak juga telah terbentuk, dan mulai lebih komplek dalam beberapa bulan.

Selama janin tumbuh dan berkembang, total cairan tubuh menurun dari 92 menjadi 72 persen. Perubahan ini diikuti oleh peningkatan protein dan lemak terutama selama dua bulan terakhir kehamilan, di mana peningkatan protein lebih banyak dari pada lemak. Pada janin terjadi pula pertambahan pada natrium, kalsium dan besi. $\mathrm{N}$ atrium terutama terdapat dalam cairan ekstraseluler dan dalam tulang, sedang kalium terdapat dalam cairan intraseluler berkaitan dengan massa sel.

Kegiatan janin selama dalam kandungan selain menghisap zat gizi dan bernafas, janin juga bergerak aktif seperti menyepak, berputar, melengkung dan menggenggam. Selain itu janin mampu melakukan respon terhadap rangsangan suara atau getaran. Janin juga peka terhadap kondisi kejiwaan ibunya, misalnya ibu yang

${ }^{15}$ P. Rosso, N utrition M etbolism in Pregnancy (New York: O xford University Press, 1990). 
mengandung merasa takut, sedih atau cemas maka janin akan melakukan gerakan-gerakan yang lebih cepat. D emikian pula apabila si ibu kelelahan. Respon tersebut diduga karena adanya perubahan sekresi kelenjar yang terjadi dalam tubuh ibunya.

Pertumbuhan dan perkembangan janin dapat dibagi berdasarkan trimester:

\section{T rimester pertama}

Pada trimester pertama atau tiga bulan pertama masa kehamilan merupakan masa dimana system organ prenatal dibentuk dan mulai berfungsi. Pada minggu ke 3 sel-sel mulai membentuk organ-organ spesifik dan bagian-bagian tubuh. M inggu ke 13, jantung telah lengkap dibentuk dan mulai berdenyut, sebagian besar organ telah dibentuk,dan janin mulai dapat bergerak.

Bagi wanita hamil tentu saja masa trimester pertama ini merupakan masa penyesuaiannya baik secara fisik maupun emosi dengan segala perubahan yang terjadi dalam rahimnya. Pada trimester pertama ini ibu sering mengalami mual atau, ingin muntah, tidak selera makan yang sering dikenal dengan "morning sickness", yang dapat menyebabkan berkurangnya intik makanan ibu. ${ }^{16}$

Defisiensi gizi dan pengaruh-pengaruh lain yang membahayakan janin seperti penggunaan obat, vitamin A dosisi tinggi, radiasi atau trauma dapat merusak atau menghambat perkembangan janin selanjutnya. Sebagain besar keguguran terjadi pada masa ini, bahkan sekitar sepertiga dari kejadian keguguran terjadi karena wanita tidak menyadari bahwa dia sedang benarbenar hamil. M asa trimester pertama merupakan masa yang kritis, sehingga harus dihindari hal-hal yang memungkinkan kegagalan pertumbuhan dan perkembangan janin. ${ }^{17}$

\section{Trimester kedua}

Pada awal trimester kedua, berat janin sudah sekitar $100 \mathrm{~g}$. Gerakan-gerakan janin sudah mulai dapat dirasakan ibu. Tangan, jari, kaki dan jari kaki sudah terbentuk, janin sudah dapat

\footnotetext{
${ }^{16}$ Michio and Kushi, A. Macrobiotic Pregnancy: and Care of the Newborn (Tokyo and New York: Japan Publication, Inc., 1985).

${ }_{17}$ W ardlaw, G., Insel, P.M . and Seyler, M.F, Contemporary Nutrition (St.Louis-Baltomore-BostonChicago-London-Philad elpia-Sydney-To ronto: M osby Y ear Book, 1992).
} 
mendengar dan mulai terbentuk gusi, dan tulang rahang. O rganorgan tersebut terus tumbuh menjadi bentuk yang sempurna, dan pada saat ini denyut jantung janin sudah dapat dideteksi dengan stetoskop. Bentuk tubuh janin saat ini sudah menyerupai bayi.

\section{T rimester ketiga}

M emasuki trimester ketiga, berat janin sekitar 1-1,5 kg. Pada periode ini uterus semakin membesar sampai berada di bawah tulang susu. U terus menekan keatas ke arah diafragma dan tulang panggul. $\mathrm{H}$ al ini sering membuat ibu hamil merasa jantung sesak dan kesulitan pencernaan. Seringkali ibu juga mengalami varises pada pembuluh darah sekitar kaki, wasir, dan lutut keram karena meningkatnya tekanan kepada perut, rendahnya laju darah balik dari limbs, dan efek dari progesterone, yang menyebabkan kendurnya saluran darah.

Setelah usia kehamilan mencapai sekitar 28 -30 minggu, bayi yang lahir disebut prematur (sebelum minggu ke 37 kehamilan), mempunyai kesempatan untuk hidup baik bila dirawat dalam suatu perawatan "bayi baru lahir risiko tinggi". N amun, mineral dan cadangan lemak pada bayi tidak normal, yang seharusnya dibentu pada bulan terakhir kehamilan. M asalah medis lain pada bayi prematur adalah masih belum mampu mengisap dan menelan dengan baik, sehingga perawatan bayi ini sangat sulit. ${ }^{18}$

\section{b. Periode Setelah K elahiran (pasca natal atau post natal)}

Setelah lahir, manusia mengalami proses pertumbuhan dan perkembangan yang terdiri dari beberapa periode, yaitu masa neonatal, masa bayi (bayi dini dan bayi lanjut), masa prasekolah, masa sekolah atau pra-pubertas dan masa remaja (adolescent). ${ }^{19}$

1. M asa neonatal (0-30 hari)

Tahap awal neonatus adalah beradaptasi terhadap lingkungan, yang termasuk perubahan sirkulasi darah dan mulainya berfungsi berbagai organ-organ tubuhnya yang lain seperti parunya. Periode neo-natal merupakan periode tersingkat dalam proses perkembangan. $\mathrm{M}$ asa ini adalah masa terjadinya

\footnotetext{
${ }^{18} \mathrm{lbid}$.

19 Tanuwidjaya S., "Konsep Umum Tumbuh dan Kembang" dalam: Nahendra (penyunting) Tumbuh Kembang Anak dan Remaja, Edisi Pertama (Jakarta: Sagung Seto, 2002).
} 
penyesuaian yang radikal, masa terhentinya perkembangan pranatal dan masa pendahuluan perkembangan bayi dan perkembangan selanjutnya. Masa neonatal merupakan periode yang sangat berbahaya.

2. M asa bayi (1-24 bulan)

M asa berikutnya adalah masa bayi, yang terbagi dua masa yaitu bayi dini dan bayi lanjut. Fase bayi dini yang berawal dari usia 1 bulan hingga 12 bulan. Pada fase bayi dini pertumbuhan akan terjadi dengan pesat dan proses pematangan organ akan berlangsung secara berkelanjutan terutama meningkatnya fungsi sistem saraf.

Setelah bayi mencapai usia 1 tahun, ia akan masuk ke masa bayi akhir, yang berlangsung hingga ia mencapai usia 2 tahun, di tahap ini kecepatan pertumbuhan mulai menurun dan ada kemajuan pada perkembangan motorik dan fungsi ekskresi.

3. M asa prasekolah (2-5 tahun)

Pada saat usianya masuk 2 tahun, dia akan memasuki tahap prasekolah (preschooler), di usia ini pertumbuhan anak akan berlangsung dengan stabil dan terjadi perkembangan dengan aktifitasnya sehari-hari dan meningkatnya keterampilan dan proses berpikir.

4. M asa sekolah atau pra-pubertas (6-24 bulan)

$M$ asa sekolah atau masa prapubertas terjadi pada anak wanita dikalangan usia 6 hingga 10 tahun, sedangkan anak laki laki usia 8 hingga 12 tahun, diperiode ini anak-anak akan mengalami pertumbuhan yang lebih cepat dibandingkan dengan masa prasekolah, keterampilan dan intelektual makin berkembang, dia senang bermain berkelompok dengan jenis kelamin yang sama.

5. M asa remaja (adolescent)

Anak wanita biasanya akan memasuki masa adolesensi 2 tahun lebih cepat dibandingkan anak laki-laki. U sia anak wanita memasuki masa adolesensi adalah antara usia 10 hingga 18 tahun, sedangkan anak laki-laki akan mengalami masa ado lensensi diusia 12 hingga 20 tahun. Masa ini merupakan transisi periode anak memasuki tahap menjadi seorang dewasa. Ada terjadi percepatan pertumbuhan berat badan dan tinggi badan yang sangat pesat yang disebut Adolescent Growth Spurt yang disertai juga dengan 
terjadi pertumbuhan dan perkembangan pesat dari alat kelamin dan timbulnya tanda-tanda kelamin sekunder.

\section{Perkembangan $\mathrm{M}$ anusia $\mathrm{M}$ enurut $\mathrm{Al}-\mathrm{Q}$ ur'an dan $\mathrm{H}$ adis}

Fase perkembangan manusia dalam al-Q ur'an disebutkan dalam surat al-H ajj ayat 5 , berikut:

"H ai manusia, jika kamu dalam keraguan tentang kebangkitan (dari kubur), mMaka (ketahuilah) sesungguhnya Kami telah menjadikan kamu dari tanah, kemudian dari setetes mani, kemudian dari segumpal darah, kemudian dari segumpal daging yang sempurna kejadiannya dan yang tidak sempurna, agar Kami jelaskan kepada kamu dan Kami tetapkan dalam rahim, apa yang Kami kehendaki sampai waktu yang sudah ditentukan, kemudian Kami keluarkan kamu sebagai bayi, kemudian (dengan berangsurangsur) kamu sampailah kepada kedewasaan, dan di antara kamu ada yang diwafatkan dan (adapula) di antara kamu yang dipanjangkan umurnya sampai pikun."

Berdasarkan ayat di atas, fase perkembangan manusia menurut alQ ur'an dapat dibagi menjadi: fase pranatal, fase pasca natal, fase kanakkanak, fase tamyîz, fase amrad, fase taklif, dan fase pasca kematian.

Pada fase pranatal, perkembangan manusia disebutkan dalam alQ ur'an surat al-M u'minum ayat 12-14:

" $D$ an Sesungguhnya Kami telah menciptakan manusia dari suatu saripati (berasal) dari tanah (12). Kemudian Kami jadikan saripati itu air mani (yang disimpan) dalam tempat yang kokoh (rahim) (13). Kemudian air mani (nuthfah) itu Kami jadikan segumpal darah ('alaqah), Ialu segumpal darah itu Kami jadikan segumpal daging (mudghah), dan segumpal daging itu Kami jadikan tulang belulang ('idham), lalu tulang belulang itu Kami bungkus dengan daging (lahm). Kemudian Kami jadikan dia makhluk yang (berbentuk) lain. M aka M aha sucilah Allah, Pencipta Yang Paling Baik (14)."

Dari ayat di atas, proses kejadian manusia dapat dibagi dalam 6 periode, yaitu:

1) D ari saripati tanah

2) Periode air mani yang membuahi ovum menjadi nuthfah

3) Periode nuthfah menjadi ‘alaqoh 
4) Periode 'alaqah menjadi segumpal daging (mudghah)

5) Periode mudghah menjadi tulang belulang ('idham)

6) Periode 'idham menjadi tulang belulang yang dibungkus daging (lahm), kemudian Allah jadikan makhluk yang berbeda dari sebelumnya yaitu manusia.

Ada juga hadis yang memberikan penjelasan tentang perkembangan anak dalam kandungan, berikut:

Dari Abdullah berkata: Rasulullah saw bersabda: Sesungguhnya setiap orang dari kamu terkumpul (masa) kejadiannya di dalam perut ibunya 40 hari dalam bentuk nuthfah, kemudian menjadi 'alaqah sama jumlah masanya dengan itu (40 hari), lalu menjadi mudghah sama jumlah masanya dengan itu (40 hari). Kemudian diutus kepadanya malaikat lalu dihembuskannyalah roh kepadanya. (H adis M uttafaq 'alaih dari Abdullah)

Dari hadis di atas, dijelaskan bahwa periode nuthfah (zigot) adalah 40 hari, periode 'alaqah (embrio) 40 hari, dan periode mudghah (janin) 40 hari (dalam periode mudghah ini ketika janin telah genap berusia 4 bulan dan janin manusia telah terbentuk secara sempurna, janin manusia diberi hidup oleh Allah melalui tiupan roh oleh malaikat). I tu berarti bahwa periode fi dzulumatin tsalats yang disebut dalam al-Q ur'an adalah 120 hari $(3 \times 40)$, yaitu mulai sejak saat terjadinya 'perkawinan' antara sperma dan ovum di dalam rahim sampai dengan terbentuknya tulang belulang yang terbungkus daging dan ditiupkan roh kepadanya. Sedang 150 atau 160 hari sesudahnya adalah periode manusia hidup bernyawa sampai dengan lahir. ${ }^{20}$

Penjelasan ayat al-Q ur'an dan hadis tentang perkembangan manusia 15 abad silam ini telah menjadi bahan penelitian para ahli biologi untuk memperdalam ilmu tentang jasad manusia. Para ahli dari barat baru menemukan masalah pertumbuhan embrio secara bertahap pada tahun 1940 dan baru dibuktikan pada tahun 1955. Namun al-Qur'an dan hadis yang diturunkan 15 abad yang lalu telah menceritakan hal tersebut secara rinci. $\mathrm{H}$ al ini membuat kagum salah seorang embriolog dari Amerika yaitu Prof. Dr. Keith M oore. ${ }^{21}$

\footnotetext{
${ }^{20}$ Baihaqi A. K., M endidik Anak dalam Kandungan Menurut Ajaran Pedago gis Islami (Jakarta: Darul Ulum Press, 2003), 37-38.

${ }^{21}$ M. Q uraish Shihab, Tafsir al-Mishbah Pesan, Kesan dan Keserasian al-Q ur'an Vol 10 (Jakarta: Lentera Hati, 2002).
} 
Dan Surat al-Hajj ayat 5 dijelaskan tentang fase perkembangan manusia pascanatal, yaitu:

1) Fase bayi dan anak-anak (thifl) yaitu masa sejak persalinan hingga menjadi anak-anak yang mulai beranjak remaja,

2) Fase baligh hingga dewasa (litablughu asyuddakum), yaitu masa ketika perubahan mendasar dalam kehidupan terjadi. Pada wanita ditandai dengan haid (menstruasi) dan pada pria berupa intilam (mimpi basah, mimpi- dewasa). Dari segi mental, pada usia ini dianggap telah mampu bertanggungjawab sehingga tonggak taklif dimulai dari sini,

3) Fase lanjut usia yaitu fase ketika melewati masa puncak kekuatan fisik Ialu menurun kembali menjadi tidak berdaya. Dalam pertumbuhan dan perkembangan individu disetiap fasenya ada prose yang sistematik, progresif dan berkesinambungan.

Allah menjelaskan bagaimana proses individu tumbuh dan berkembang menjalani fase demi fase kehidupannya sebagaimana dalam firman Allah QS. Al-M u'min ayat 67. M anusia merupakan makhluk hidup yang lebih sempurna bila dibandingkan dengan makhluk yang lainnya. Akibat dari unsur kehidupan yang ada pada manusia, manusia berkembang dan mengalami perubahan-perubahan, baik perubahan dalam segi fisiologis maupun perubahan-perubahan dalam segi psikologis. Di dalam al-Quran juga menjelaskan gambaran penciptaan manusia secara detail dan perkembangan manusia pada fase yang berbeda.

\section{Pembentukan Kualitas Anak pada 1000 H ari Pertama Kehidupan dalam Islam}

D alam I slam, pembentukan kualitas anak telah dimulai sejak sangat dini, yakni mulai dari pemilihan jodoh. $D$ ari segi batasan pembentukan kualitas anak pada 1000 H PK, dapat dibagi menjadi beberapa periode, yaitu: periode pemilihan jodoh, periode pernikahan, periode kehamilan dan periode setelah kelahiran.

1) Periode pemilihan jodoh

Periode ini merupakan awal masa persiapan proses pembentukan kualitas anak. Pada periode ini, merupakan periode persiapan bagi 
seorang yang sudah dewasa untuk berkeluarga. D alam I slam, seorang lelaki atau perempuan dianjurkan untuk memilih jodoh yang tepat. Syari'at Islam telah meletakkan kaidah dan hukum bagi masingmasing pelamar dan yang dilamar. Bila hal ini dilaksanakan, makapernikahan akan mencapai puncak keharmonisan, kecintaan dan keserasian. ${ }^{22}$

Dalam hadis, Rasulullah saw telah memberikan gambaran tentang pemilihan calon suami atau istri. Sebagaimana H R. Bukhari $M$ uslim berikut yang memberikan kategori calon istri menurut syariat Islam.

"Wanita itu dinikahi karena empat hal, karena hartanya, keturunannya, kecantikannya, agamanya. Pilihlah wanita yang memiliki agama, niscaya engkau beruntung." (HR. Bukhari M uslim) $)^{23}$

D alam hadis lain juga disebutkan, yang artinya:

"Pilihlah tempat menanam nuthfahmu (istri), karena pengaruh keturunan itu sangat kuat." (H R. A bu D aud) ${ }^{24}$

D alam kitab-kitab fikih dan hadis, disebutkan beberapa hal yang penting untuk memilih calon istri, di antaranya: saling mencintai antara kedua calon mempelai, memilih wanita karena agamanya, wanita yang sholehah, memiliki derajat yang sama dengan calon suami (sekufu'), wanita yang hidup di lingkungan yang baik, wanita yang jauh keturunannya dan jangan memilih wanita yang dekat keturunannya sebab dapat menurunkan anak yang lemah jasmani dan bodoh, memilih wanita yang masih gadis dan subur (bisa melahirkan).

Sedangkan dalam memilih calon suami, Rasulullah saw bersabda yang artinya: "A pabila orang yang agamanya dan akhlaknya bagus datang kepadamu (untuk melamar anak perempuanmu), maka nikahkanlah dia. Kalau tidak kamu lakukan, hal itu berpotensi

\footnotetext{
${ }^{22}$ Ramayulis, IImu Pendidikan Islam (Jakarta: Kalam M ulia, 2011), 302.

${ }^{23}$ Abi A bdillah M uhammad bin Ismail Al-Bukhari, Shahih Bukhari, Kitab Nikah (67), hadis no. 5090 (Riyadh: Baitul akfar al-Dauliyah li an-N asyr, 1998), 1009.

${ }^{24}$ Hasan Ali al-Halabi, Mausu'ah al-Ahadits wa al-Atsar ad-Dha'ifah wa al-M audhu'ah, no. 8041

(Riyadh: Maktabah al-Ma'arif li an-Nasy wa at-Tauzi', 1999), 528.
} 
menimbulkan fitnah dan kerusakan besar di muka bumi." (HR. T irmidzi $)^{25}$

Berdasarkan hadis-hadis di atas, dapat dipahami bahwa membentuk anak yang berkualitas harus diupayakan sedini mungkin, yakni semenjak calon suami atau istri memilih jodohnya. $\mathrm{Hal}$ ini karena pembawaan dari kedua calon orangtua bayi sangat kuat. Pribadi yang saleh dari calon orangtua relatif akan menurun kepada pribadi anak-anak yang bakal dilahirkannya. ${ }^{26}$

Pemilihan jodoh yang tepat sesuai dengan kriteria syari'at Islam, akan meningkatkan martabat manusia di masa depan. $\mathrm{H}$ al ini karena anak yang lahir dari keluarga bahagia, suami yang sholeh dan istri yang shalehah, akan diasuh serta dididik untuk selalu taat beragama dan nantinya akan menjadikan anak yang shaleh setelah dewasa. Dengan demikian, pemilihan jodoh merupakan langkah penting pertama kali yang harus dilakukan untuk mendapatkan keturunan yang berkualitas.

2) Periode pernikahan

Periode pernikahan merupakan lanjutan dari periode pemilihan jodoh. Ketika jodoh yang tepat sudah dipilih, kemudian diadakan peminangan dan selanjutnya dilaksanakan pernikahan. Pernikahan merupakan suatu ikatan lahir batin antara seorang laki-laki dan perempuan yang bukan muhrim sebagai suami istri dengan tujuan membina suatu rumah tangga yang bahagia berdasarkan tuntunan Allah swt. M enurut $\mathrm{U}$ shul Figh, golongan $\mathrm{H}$ anafi mengatakan nikah menurut arti sebenarnya berarti setubuh (bahda'a) dan menurut arti majazinya (kiasan) berarti akad di mana dengan akad itu dapat menghalalkan hubungan kelamin antara laki-laki dengan perempuan. ${ }^{27}$

Tujuan pernikahan menurut syari'at I slam, tidak hanya untuk memelihara pandangan dan kemaluan dari kemaksiatan saja. $\mathrm{N}$ amun juga bertujuan untuk melaksanakan sunnah Rasul, melahirkan keturunan yang dapat meneruskan risalahnya, memelihara keturunan,

\footnotetext{
${ }^{25} \mathrm{Abi}$ 'Isa M uhammad bin 'Isa bin Saurah at-Tirmidzi, Jami' at-Tirmid zi, Kitab Nikah (8), hadis no. 1058 (Riyadh: Baitul akfar al-Dauliyah, t.th), 192.

${ }^{26}$ M. N ipan Abdul Halim, Anak Saleh Dambaan Keluarga (Yogyakarta: M itra Pustaka, 2003), 158159.

${ }^{27}$ Ibrahim Hosen, Fiqh Perbandingan Masalah Pernikahan (Jakarta: Pustaka Firdaus jilid 1, 2003), 115.
} 
tempat menyemaikan bibit iman, melahirkan keluarga sehat, serta memenuhi dorongan rasa ketentraman dan kasih sayang (sakinah, mawaddah wa rahmah).

Dalam syari'at Islam, ada syarat-syarat yang harus dipenuhi untuk melaksanakan pernikahan, yaitu: dua orang calon mempelai, wali, ijab qabul, dua orang saksi, dan mahar. ${ }^{28}$

Setelah pernikahan selesai, maka suami istri sudah halal untuk mulai bergaul dengan melakukan persetubuhan. D alam syari'at Islam, sebelum bersetubuh, disunnahkan membaca doa yang artinya: "D engan nama Allah, ya Allah jauhkanlah syetan dari kami dan jauhkanlah syetan itu dari anak yang (mungkin) Engkau karuniakan kepada kami." Doa tersebut mengandung unsur pedagodis bahwa lewat doa ini, calon orang tua telah mendidik dirinya dan cikal bakal anaknya untuk senantiasa dekat kepada Allah dengan harapan yang besar anaknya kelak menjadi hamba Allah yang sholeh. ${ }^{29}$

Allah swt telah mensyariatkan pernikahan agar terpeliharanya keturunan manusia. Dalam al-Qur'an, Allah swt telah menjadikan manusia itu saling berpasangan, menghalalkan pernikahan dan mengharamkan zina. Pernikahan merupakan cara yang halal dan suci untuk menyalurkan syahwat. Dengan adanya pernikahan, akan memelihara kesucian diri, melahirkan keturunan yang berguna bagi agama, bangsa dan negara, memperoleh ketenangan hidup dan kasih sayang. Anak yang dilahirkan dan dibesarkan dari pernikahan dengan orangtua (bukan hasil zina), akan lebih terdidik dan terarah kehidupannya. Sebaliknya, anak hasil zina yang dibesarkan tanpa orangtua akan memudahkan anak terjerumus ke dalam kegiatan yang tidak bermoral.

3) Periode kehamilan

Periode kehamilan terjadi ketika telah terjadi pembuahan yakni pertemuan antara sel telur dan ovum. Secara umum, periode kehamilan berlangsung kurang lebih 9 bulan 10 hari. Periode ini memberikan makna yang sangat penting bagi proses pembentukan kepribadian manusia berikutnya.

\footnotetext{
${ }^{28}$ Ibnu Rusyd, Bidayatul Mujtahid, (terj), MA. Abdurrahman dan A. Haris Abdullah (Semarang: Assyifa, 1990), 384.

${ }^{29}$ Ramayulis, IImu Pendidikan Islam, 308.
} 
Islam telah mengajarkan umatnya dari agar senantiasa memohon kepada Allah supaya dikaruniai anak yang shaleh. Sebagaimana firman Allah swt dalam surat As-Shaffat ayat 100 yang artinya: "Ya T uhanku, berilah aku anak yang shaleh".

AI-Qur'an dan hadis telah menjelaskan secara rinci tentang tahapan kehamilan atau proses pembentukan manusia sebagaimana yang telah disebutkan pada bagian sebelumnya. Pada masa kehamilan dari mulai bulan pertama hingga keempat yakni dari bentuk awal berupa nuthfah hingga menjadi mudghah, kehidupan masih bersifat biologis. Setelah $\mathrm{M}$ alaikat meniupkan ruh kepada mudghah tersebut, maka kehidupan manusia sudah bertambah dengan aspek psikis.

Pada bulan keempat, jantung janin mulai bekerja. Getarannya sudah dapat dipantau dengan shetescope. Semenjak itu, ia sudah bisa bergerak. Semakin lama semakin kuat getarannya. Selain itu, adanya ruh atau jiwa pada janin telah membuatnya dapat merasa, berfikir, mengingat, membayangkan, mengangan-angan, dan sebagainya. Semua itu menunjukkan adanya kehidupan jiwanya.

Di sisi lain, keberadaan kehidupan psikis bisa dibuktikan dengan mengaitkan kebahagiaan ataupun penderitaan batin sang ibu dengan bayi yang dikandung. Kebahagiaan, kelincahan, ketenangan yang senantiasa ditunjukkan oleh seorang ibu ketika sedang mengandung, akan tercermin pada bayinya kelak setelah lahir. Begitu pula sifat-sifat lain seperti murung, dengki, sombong yang ditunjukkan ketika mengandung, akan juga diwarisi oleh sang bayi kelak.

Selain aspek biologis dan psikis selama masa dalam kandungan, terdapat juga aspek agama bagi janin. Sebagaimana ungkapan alQur'an yang menyebutkan bahwa secara fitrah, manusia adalah makhluk yang beragama. Karena secara naluri, manusia pada hakikatnya selalu mengakui adanya Tuhan yang $M$ aha Esa. Sehingga, manusia memiliki potensi kesiapan untuk mengenal dan mengakui keberadaan T uhan. ${ }^{30}$

Pada periode kehamilan yang merupakan awal kehidupan seorang manusia, setiap janin terlindung dari semua pengaruh kondisi luar kecuali yang dapat sampai kepada ibu yang sedang mengandungnya. Oleh karena itu, seorang ibu yang sedang mengandung diwajibkan untuk makan makanan yang bergizi;

\footnotetext{
${ }^{30} \mathrm{lbid}, 309-310$.
} 
menghindari benturan-benturan; menjaga emosi dari perasaan sedih yang berlarut-larut atau marah yang meluap-luap; menjauhi minuman keras, merokok, berbagai jenis makanan yang diharamkan Allah swt; menjaga rahim agar jangan sampai terkena penyakit atau infeksi. ${ }^{31}$ D engan pemeliharaan tersebut, akan menjadikan janin lahir menjadi anak yang sehat jasmani dan rohaninya.

Selanjutnya, selama proses kehamilan tersebut, orangtua terutama ibu dianjurkan untuk:

a. Banyak bersyukur dan bergembira atas kehamilannya.

b. M enjaga agar selalu makan makanan yang halal dan baik, jangan sampai memakan dan meminum sesuatu yang syubhat atau bahkan haram. ${ }^{32}$

c. Selalu mendoakan anaknya agar menjadi anak yang shaleh.

d. M endekatkan diri kepada Allah swt melalui ibadah wajib maupun sunnah seperti membaca al-Qur'an atau mendengarkannya, dan puasa sunnah.

e. Berakhlak mulia karena akhlak orangtua mempunyai pengaruh yang besar dan menjadi rangsangan yang positif bagi anak dalam kandungan.

f. Senang dan cinta terhadap orang-orang yang shalih, agar anaknya kelak mendapat berkat keshalihan dari orang-orang shaleh tersebut.

g. M emenuhi segala kebutuhan meliputi kebutuhan makanan, kasih sayang, pengharapan, dsb.

Pembentukan kualitas anak pada saat kehamilan dirancang untuk menstimulasi anak dalam kandungan, sehingga stimulasi

\footnotetext{
${ }^{31} \mathrm{lbid}, 311$.

32 Firman Allah swt surat an-Nahl ayat 114: "Maka makanlah yang halal lagi baik dari rezki yang telah diberikan Allah kepadamu; dan syukurilah nikmat Allah, jika kamu hanya kepada-Nya saja menyembah." Menurut disiplin ilmu biologi, makanan yang baik dan bergizi itu memiliki pengaruh yang besar terhadap pematangan ovum dan spermatozoa yang kemudian akan menjadi janin yang sehat dan kuat.

Adapun makanan yang syubhat atau bahkan haram akan sangat berpengaruh terhadap perangai anak yang dilahirkan kelak. Sebagaimana sabda Nabi Muhammad saw, yang artinya: "Setiap daging yang tumbuh dari sesuatu yang haram, neraka lebih berhak baginya." Makanan yang shubhat atau bahkan haram itu pasti dapat menimbulkan dampak negatif pada jiwa orang yang mengkonsumsinya.
} 
tersebut diterapkan melalui ibu yang sedang mengandung karena ibu berinteraksi secara langsung dengan janin yang dikandungnya.

4) Periode setelah kelahiran

Pada periode ini, terdiri dari berbagai fase kehidupan, yakni: fase bayi (0-2 tahun), fase kanak-kanak (2-6 tahun), fase anak-anak (6-12 tahun), fase remaja (12-21 tahun), dan fase dewasa (22-60 tahun). Pada bagian ini akan dibahas fase bayi saja yang memiliki rentang antara 0-2 tahun.

Fase bayi terhitung dari saat kelahiran sampai kira-kira berumur 2 tahun. Selama rentang waktu itu, kehidupan bayi sangat bergantung pada bantuan dan pemeliharaan orang lain, terutama ibu. O leh karena itu, peranan ibu sangat penting dan sedemikian besarnya bagi bayi.

D i antara perkembangan yang menonjol pada periode ini adalah indera pendengaran. Indera pendengaran yang berfungsi cepat harus dimanfaatkan untuk mendengarkan kata-kata yang suci, seperti ayatayat al-Q ur'an. $\mathrm{Hal}$ ini untuk melestarikan dan mengembangkan naluri tahudi yang telah diterima jauh sebelum masa kelahirannya.

Pada periode, ada beberapa hal yang harus dilakukan oleh orang tua sesuai dengan syari'at I slam, yaitu:

a. M enyuarakan adzan dan iqomah di telinga bayi sesaat setelah lahir sebagai penegasan kesaksiannya pada Allah swt.

Untuk menguatkan potensi fitrah manusia dalam bertuhan. Jika fungsi pendengarannya dioptimal kan pada fase ini, maka akan menstimulus potensi-potensi intelektual, emosi dan spiritual pada anak. Jika orang tua memperdengarkan hal-hal baik pada anaknya, maka hal tersebut sangat berdampak baik bagi pengetahuannya. ${ }^{33}$

b. M emberikan nama yang baik

Ini merupakan hal yang penting dalam perkembangan anak selanjutnya. Nama-nama yang baik akan menjadi doa dan terinternalisasikan pada anak.

c. M enyusui anak selama dua tahun penuh

${ }^{33}$ Sebagaimana ibunda Imam Syafi'i yang selalu memperd engarkan ayat-ayat al-Q ur'an sejak lahir dengan intens dan konsisten, ketika menyusui, ibunya sambil bersenandung membaca al-Q ur'an, sehingga Imam Syafi'i telah mampu menghafalkan al-Q ur'an pada umur 7 tahun. Seperti ia hanya mengulang saja apa yang telah ia dengar sejak bayi dari ibunya. 
Selain karena gizi yang terdapat dalam ASI tetapi juga untuk membangun keeratan, kasih sayang antara ibu dan anak. Sebagaimana dalam al-Q ur'an surat al-Baqarah ayat 233, yang artinya: "Para ibu hendaklah menyusukan anak-anaknya selama dua tahun penuh, Yaitu bagi yang ingin menyempurnakan penyusuan."

Anjuran syariat tersebut akan memberikan bekal dasar yang kuat bagi seorang anak untuk menjadi anak yang berkualitas, sehat, cerdas dan berakhlak mulia. Pada bulan-bulan berikutnya hingga usia dua tahun, bayi telah mengalami perkembangan yang pesat dari segi fisik dan psikisnya. Lima indera yang dimilikinya telah berfungsi, dan ia telah dapat mengucapkan kata-kata, menangkap isyarat, berjalan, dan sebagainya. Perkembangan-perkembangan harus digunakan semaksimal mungkin untuk menanamkan nilai-nilai agama. Seperti mengajak untuk shalat, membacakan al-Qur'an ketika menyusui, mendendangkan shalawat ketika menggendong, dan sebagainya. Walaupun masih sederhana, namun yang demikian tersebut justru merupakan moment yang menentukan bagi perkembangan bayi selanjutnya.

\section{Simpulan}

Periode 1000 H PK dimulai sejak masa kehamilan hingga menyusui sampai usia anak 2 tahun merupakan waktu ketika organ-organ penting bayi mulai terbentuk. Pada bulan keempat kehamilan, sistem pendengaran mulai terbentuk. Bersamaan itu juga bayi mulai dapat merasakan stimulus yang diberikan dari luar, merekam dan menirukan komunikasi serta kebiasaan-kebiasaan yang dilakukan oleh ibunya yang akan ia bawa hingga seterusnya. Oleh karena itu, kebutuhan janin terutama gizi, emosi dan stimulus harus dipenuhi. Kekurangan rangsangan dan terutama gizi pada masa ini, akan berdampak besar dalam jangka panjang kehidupannya, di antaranya terserang penyakit kronis atau bahkan bisa lahir cacat.

Islam telah memberikan tuntunan untuk membentuk anak yang berkualitas pada 1000 H PK, bahkan sejak masa pra-pernikahan. Dari segi batasan pembentukan kualitas anak pada 1000 H PK, dapat dibagi menjadi beberapa periode, yaitu: periode pemilihan jodoh, periode pernikahan, periode kehamilan dan periode setelah kelahiran. Pada tahap 
pemilihan jodoh dianjurkan memilih jodoh terutama berdasarkan agamanya. Pada tahap pernikahan, dilangsungkan sesuai syari'at Islam dalam rangka melestarikan keturunan, tidak dengan zina, serta bersenggama dengan cara yang baik sesuai dengan tuntunan syari'at Islam. Ketika masa kehamilan, dianjurkan banyak bersyukur dan bergembira, makan makanan yang halal dan baik, memperbanyak ibadah, dsb. Pasca kelahiran, dituntun untuk membacakan adzan dan iqamah di telinga bayi yang baru lahir, memberikan nama yang baik, dan menyusui anak selama 2 tahun penuh. Tuntunan-tuntunan tersebut memberikan bekal dasar yang kuat bagi seorang anak untuk menjadi anak yang berkualitas, sehat, cerdas dan berakhlak mulia.

\section{D aftar Rujukan}

Achadi, Endang L.. Periode Kritis $1000 \mathrm{H}$ ari Pertama Kehidupan dan Dampak Jangka Panjang Terhadap Kesehatan dan Fungsinya. Dalam kursus penyegar ilmu gizi yang diselenggarakan oleh PERSAGI, di Yogyakarta, 25 N ovember 2014.

Baihaqi A. K. M endidik Anak Dalam Kandungan M enurut Ajaran Pedagogis I slami. Jakarta: D arul U lum Press, C et. ke III, 2003.

BN , M oersintowarti. T umbuh kembang Anak dan Remaja, Buku ajar I. Jakarta: Penerbit CV Sagung Seto, 2004.

Bukhari (Al-), Abi Abdillah Muhammad bin Ismail. Shahih Bukhari, Kitab Nikah (67), hadis no. 5090. Riyadh: Baitul akfar alD auliyah li an-N asyr, 1998.

Ghazali (AI-). Ihya' Ulumuddin Juz III. Semarang: Maktabah wa $M$ athba'ah Toha Putra, t.th.

$\mathrm{H}$ alabi (al-), H asan Ali. M ausu'ah al-Ahadits wa al-Atsar ad-D ha'ifah wa al-M audhu'ah, no. 8041. Riyadh: M aktabah al-M a'arif li an-N asy wa at-T auzi', 1999.

Halim, M. N ipan Abdul. Anak Saleh Dambaan Keluarga. Yogyakarta: M itra Pustaka, 2003.

H alim, M. N ipan Abdul. Anak Saleh Dambaan Keluarga. Yogyakarta: M itra Pustaka, 2003.

Hamidah, Atien Nur. Pentingnya Stimulasi Dini Bagi Tumbuh Kembang $O$ tak Anak. M ateri Talk Show "T umbuh Kembang dan Kesehatan Anak" di UNY tanggal 170 ktober 2009. 
H idayat, A. Azis Alimul. Pengantar IImu Keperawatan Anak 1. Jakarta: Salemba M edika, 2005.

Hosen, Ibrahim. Figh Perbandingan Masalah Pernikahan. Jakarta: Pustaka Firdaus Jilid 1, 2003.

H urlock, Elizabeth B. Perkembangan Anak Jilid I. Jakarta: Erlangga, 1999.

Michio and Kushi, A. Macrobiotic Pregnancy: and Care of the N ewborn. Tokyo and N ew York: Japan Publication, Inc., 1985.

Purwakania, Aliah B. Psikologi Perkembangan Islam. Jakarta: Raja Grafindo Persada, 2006.

Ramayulis. IImu Pendidikan Islam. Jakarta: Kalam M ulia, 2011.

Rosso, P. Nutrition Metbolism in Pregnancy. New York: Oxford U niversity Press, 1990.

Rusyd, Ibnu. Bidayatul Mujtahid, (terj), MA. Abdurrahman dan A. $\mathrm{H}$ aris A bdullah. Semarang: Assyifa, 1990.

S., Tanuwidjaya. Konsep Umum Tumbuh dan Kembang. Dalam:

$\mathrm{N}$ ahendra (penyunting) Tumbuh Kembang Anak dan Remaja.

Edisi Pertama, Jakarta: Sagung Seto, 2002.

Shihab, M. Q uraish. T afsir al-M ishbah Pesan, Kesan dan Keserasian alQ ur'an Vol 10. Jakarta: Lentera H ati, 2002.

Soetjiningsih. Tumbuh Kembang Anak. Jakarta: Penerbit Buku Kedokteran EGC, 1995.

Sularyo, Titi. Tumbuh kembang Anak dan Remaja, Buku ajar I. Jakarta:

Penerbit CV Sagung Seto, 2002.

Sumanto, Wasti. Psikologi Pendidikan. Jakarta: Rineka Cipta, 1990.

Suryani. Gizi - Kesehatan Ibu dan Anak. Jakarta: Dirjen Dikti. Depdiknas, 2002.

T., Suganda. Kebutuhan Dasar Tumbuh Kembang Anak. Dalam T umbuh Kembang Anak dan Remaja, editor M oersintowati, dkk. Edisi I, I katan D okter Anak Indonesia, 2002.

Tim Penyusun. Pedoman Perencanaan Program Gerakan $1000 \mathrm{H}$ ari Pertama Kehidupan. Jakarta, 2013.

Tirmidzi (at-), Abi 'Isa Muhammad bin 'Isa bin Saurah. Jami' atTirmidzi, Kitab Nikah (8), hadis no. 1058. Riyadh: Baitul akfar al-D auliyah, t.th. 
Wardlaw, G., Insel, P.M. and Seyler, M.F. Contemporary Nutrition. St.Louis-Baltomore-Boston-C hicago-London-PhiladelpiaSydney-T oronto: M osby Year Book, 1992. 